
testing properties of concrete subjected to sulfuric acid attack

15 Abstract: In order to investigate the effect of aggregates on the concrete sulfuric acid

16 resistance, accelerated corrosion experiments were conducted with four types of

17 concretes composed of coarse and fine aggregates with two different chemical

18 compositions. All the concretes with the same water/cement ratio of 0.45 , and the $\mathrm{pH}$

19 value was kept in the range of 0.93 to 0.97 . With continuous monitoring of each

20 concrete specimen, corrosion depth, mass loss, and dynamic modulus elasticity loss

*Corresponding author. Tel: +86-21-65980321; Fax: +86-21-65980321

E-mail addresses: quwenjun.tj@tongji.edu.cn (W. J. Qu), 123xiaoj@tongji.edu.cn (J. Xiao)

\title{
3 / 50
}


21 were calculated. The results showed that the dynamic modulus of elasticity loss can be regard as an acceptable indicator for evaluating the resistance of concrete to sulfuric acid attack as well as corrosion depth and mass loss. A regression model proposed in this paper could provide good predictions. Concrete with marble aggregates rich in calcium carbonate have better performances in sulfuric acid solution than that with inert aggregates. Effect of fine aggregate on concrete sulfuric acid corrosion rate is more significant than coarse aggregate in the term of corrosion depth, mass loss, and dynamic modulus of elasticity loss.

Key words: Siliceous and calcareous aggregates, Sulfuric acid attack, Dynamic modulus of elasticity, Thermodynamics, Range analysis

\section{$31 \quad 1$ Introduction}

It is recognized that the hydration products of Portland cement concrete are alkaline and the pore solution in the concrete typically has a $\mathrm{pH}$ value ranging between 12 and 13.5. So it cannot be immune from acid attack. Owing to the spread of concrete structures damages in both urban and industrial areas, concrete acidic attack has attracted more and more attention in recent years. Sulfuric acid is the most widely distributed acid medium in the environment. Sulfuric acid can be generated from the oxidation of sulfide minerals (e.g. pyrite) [1]. Sulfuric acid is also a chief component of

39 acid rain. It is reported that acid rain falls cover at least one third of Chinese territory[2].

40 Moreover, biogenic sulfuric acid corrosion is a common type of damage in sewage pipe 41 systems $[3,4]$. It is estimated that costs of maintenance and repair due to sulfuric acid 
attack are several ten billion dollars in U.S. on sewer systems, which are even more than the costs of constructing new wastewater structures $[5,6]$. Hence there is an urgent need to investigate the deterioration rules of sulfuric acid attack on concrete structures in order to minimize its impact. Several researchers [6-9] have studied the effect of cement type, cement content, water-to-cementitious materials ratio on improving the resistance of mortar or concrete to sulfuric acid attack. It has also been reported that the use of supplementary cementitious materials (SCM) such as silica fume, fly ash, blast furnace slag, limestone filler, and natural pozzolana in concrete has improved the resistance of concrete to sulfuric acid attack because of its finer pore structure and the reduced presence of calcium hydroxide, which is most vulnerable to acid attack[10-13]. But, aggregate consists $65-80$ percent of concrete proportion and has the main role in concrete behavior such as durability, dimensional stability and workability [14, 15]. Therefore, it appears necessary to better understand the deterioration mechanisms associated with aggregate when concrete subjected to sulfuric acid attack. According to the mineralogical composition, aggregate can be divided into two types: one type is calcareous aggregate which is rich in calcium carbonate and is more vulnerable to acid attack. The other type is siliceous aggregate which is rich in silicon dioxide and is more resistant to acid attack. Which type of aggregates should be chosen in the acid environment remains controversial. Some researchers are convinced that aggregate is the main component of the concrete, and the concrete corrosion process will be accelerated if the aggregate is damaged by the acid first[16]. However, other 
63 researchers have published results that concrete with coarse calcareous aggregate offers

64 better resistance to sulfuric acid attack. Hughes et al.[17] reported that the mass loss of

65 cubes with limestone coarse aggregate and siliceous sand was less than that with

66 limestone coarse and fine aggregates. In his study, only the mass loss and visual

67 inspection were researched and just three combinations of coarse and fine aggregates

68 were adopted in concrete without the cubes with siliceous coarse aggregate and

69 limestone fine aggregate. Belie et al.[18] found that the aggregate type had the largest

70 effect on concrete degradation after sulfuric acid corrosion. Concrete with limestone

71 aggregates showed a smaller degradation depth than that with inert aggregates. Chang

72 et al.[19] presented that concrete made with limestone aggregates and the ternary

73 cement containing $7 \%$ silica fume and $33 \%$ fly ash has an excellent acid resistance in

$741 \%$ sulfuric acid solution. The fine aggregate used in his study was only silica river

75 sand. Bederina et al.[20] pointed out that the mass loss in the case of limestone sand is

76 lower than that of silica sand mortar when exposed to hydrochloric acid solution.

77 However, an extensive review of literature indicates that the significance of coarse and

78 fine aggregate on the concrete sulfuric acid corrosion is not clearly clarified. In order to

79 explore the question that which has greater influence on the concrete sulfuric acid

80 resistance, coarse aggregate or fine aggregate, concretes with four different

81 combinations of aggregates were adopted in the accelerated sulfuric acid corrosion test.

82 In previous studies, mass loss and corrosion depth were regarded as acceptable

83 indicators for evaluating the resistance of concrete to sulfuric acid attack. In this paper, 
84 in addition to the above two indicators, dynamic modulus of concrete after sulfuric acid

85 corrosion was also measured through impact resonance test, which is a non-destructive

86 testing method.

87

\section{Experimental investigation}

\subsection{Raw materials}

Local Portland cement (P. I52.5R) with a 28d compressive strength of 55.3 MPa was used, which complies with Chinese standard GB175-2007 and is similar to ASTM

C150 type I cement[21]. The specific gravity of the cement was 3.1. River sand and gravel were used as fine and coarse siliceous aggregates, which come from a local pipe pile corporation at Suzhou in China. Crushed marble sand and stone were used as fine and coarse calcareous aggregates, which come from a whole rock block bought at a stone market in Shanghai, China. The phases for gravel and marble were tested with X-ray fluorescence (XRF), and the results are listed in Table 1. Because the main composition of the marble was calcium oxide $(\mathrm{CaO})$ as shown in Table 1 , marble stone and sand can be classified into calcareous aggregates category. Since the river sand is mainly composed of silicon dioxide (78.56\% in Ning Y.'s paper[22] and $88.54 \%$ in Limbachiya M.'s paper[23]), the gravel and river sand can be classified into siliceous aggregates category.

$<$ Table 1>

Gravels with a maximum nominal size of $25 \mathrm{~mm}$. and water absorption of $0.92 \%$ were obtained for concrete specimens. Table 2 shows the particle size gradation 
105 of gravel (coarse aggregates) used in the trial mixture. Natural river sand (fine

106 aggregates) with a fineness modulus of 2.61 and water absorption of $1.79 \%$ was used

107 for concrete specimens. Table 3 shows the particle size gradation of river sand used in

108 the trial mixture.

109

$<$ Table 2>

110

$<$ Table 3>

111 Marble stone and sand, cut from the same parent natural rocks, were made into

112 crushed stones by a crusher and were subsequently divided into 9 kinds of particle sizes

113 by a sieve shaker sized $0.15-0.3 \mathrm{~mm}, 0.3-0.6 \mathrm{~mm}, 0.6-1.18 \mathrm{~mm}, 1.18-2.36 \mathrm{~mm}$,

114 2.36-4.75 mm, 4.75-9.5 mm, 9.5-16 mm, 16-19 mm, 19-26.5 mm. These crushed

115 marble stones were used as coarse and fine calcareous aggregates. In order to

116 accommodate marble stone and sand with the gravel and river sand in the aspect of

117 aggregate gradation, the mass percentages of marble stone sized $2.36-4.75 \mathrm{~mm}$,

$1184.75-9.5 \mathrm{~mm}, 9.5-16 \mathrm{~mm}, 16-19 \mathrm{~mm}, 19-26.5 \mathrm{~mm}$ were 4\%, 19\%, 30\%, 22\%, 25\% (Data

119 from Table 2), respectively. The mass percentages of marble sand sized $0.15-0.3 \mathrm{~mm}$,

$120 \quad 0.3-0.6 \mathrm{~mm}, \quad 0.6-1.18 \mathrm{~mm}, 1.18-2.36 \mathrm{~mm}, 2.36-4.75,4.75-9.5 \mathrm{~mm}$ were $9.2 \%, 44.4 \%$,

$121 \quad 17.8 \%, 10.2 \%, 10.8 \%, 5.6 \%$ (Data from Table 3), respectively.

\subsection{Mixture design}

In this paper, the specimens were divided into four groups denoted by $\mathrm{C} 1 \mathrm{~F} 1$,

$124 \mathrm{C} 1 \mathrm{~F} 2, \mathrm{C} 2 \mathrm{~F} 1$, and $\mathrm{C} 2 \mathrm{~F} 2$.The coarse and fine aggregates of $\mathrm{C} 1 \mathrm{~F} 1$ were gravel and river

125 sand, C1F2 were gravel and crushed marble sand, C2F1 were crushed marble stone and 
126 river sand, and $\mathrm{C} 2 \mathrm{~F} 2$ were crushed marble stone and marble sand, respectively. The

127 water/cement ratio were 0.45 (by weight), and the mass ratio of fine aggregate to total

128 aggregate was 0.31 for all mixture proportions. Tap water with ambient temperature

129 was used. The apparent density of gravel, river sand, marble stone, marble sand were

$1302644 \mathrm{~kg} / \mathrm{m}^{3}, 2540 \mathrm{~kg} / \mathrm{m}^{3}, 2575 \mathrm{~kg} / \mathrm{m}^{3}, 2630 \mathrm{~kg} / \mathrm{m}^{3}$,respectively. Mix proportions for

131 concrete specimens are given in Table 4. Naphthalene based superplasticizer was added

132 to obtain sufficient workability. The mass ratio of superplasticizer to cement was $0.6 \%$.

133 The compressive strength at 28 days before corrosion is designed to be approximate

134 45Mpa.

135

$<$ Table 4>

$136 \quad 2.3$ Experiment design

$137 \quad$ 2.3.1 Twelve specimens preparation

138 Although both cylindrical specimen and prismatic specimen can be tested, the

139 prism corners will suffer more severe damage than that of lateral plane in the corrosion

140 environment. So the cylindrical specimen was chosen in this study. Concrete was

141 mixed in the laboratory using an electric mixer. Freshly mixed concrete was casted

142 into cylinder steel molds, which were $100 \mathrm{~mm}$ in diameter by $200 \mathrm{~mm}$ in height, and then

143 compacted on a vibration table. After that, the concrete specimens were cured $24 \mathrm{~h}$ in

144 laboratory at $18 \pm 5{ }^{\circ} \mathrm{C}$ and relative humidity about $70 \%$. Prior to the exposure to the

145 sulfuric acid solutions, all specimens were stored under standard moist curing room at

$14620 \pm 2{ }^{\circ} \mathrm{C}$ and $95 \%$ relative humidity for 28 days. 
147

148

149

150

151

152

153

154

155

156

157

158

159

160 interrupted by stirring the solution once a day. Sulfuric acid solution was refreshed

161 every month.

162

163

164

165

166 167 out that the used methods to evaluate the properties of cement based materials under

168 acidic attack embraces the observation of the changes of the appearance, mechanical
$<$ Fig. $1>$

\subsection{Test procedures}

Despite the fact that various physical and chemical tests on the resistance of concrete to acids have been developed, there are no standard procedures available to test the resistance of concrete to sulfuric acid attack [24-26]. Zivica et al.[27] pointed 
169 properties, chemical composition, pore structure, and so on. In this paper, corrosion

170 depth, mass loss and dynamic modulus of elasticity loss were used as acceptable

171 indicators for evaluating the resistance of concrete to sulfuric acid attack. During the

172 immersion period for 194 days, the cylinder specimens were periodically removed from

173 the acid solution, rinsed with tap water, and brushed gently with a plastic soft brush to

174 remove loose particles. And then the specimens were put into electric dry oven under

$17560{ }^{\circ} \mathrm{C}$ (preventing additional damage to the specimens) for 24 hours and cooled to room

176 temperature. A series of tests, including dimension measuring, weighing, and impact

177 resonance test, were conducted at regular intervals for 194 days (0days, 6 days 12

178 days, 21 days, 25 days, 37 days, 52 days, 66 days, 80 days, 108 days, 136

179 days, 164 days, 194 days) to determine corrosion depth, mass loss, and dynamic

180 modulus of elasticity loss. The specimens were reimmersed in the sulfuric acid solution

181 after periodical test.

$182 \quad$ 2.4.1 Diameter, length, and corrosion depth

183 Diameters were measured using digital vernier caliper $(0-300 \mathrm{~mm}$ range and

$1840.01 \mathrm{~mm}$ precision) at three different places along an axial plane of cylinder and the

185 other three places at right angles. Four lengths were also measured with digital vernier

186 caliper around each cylinder. The mean value of six diameters was calculated as the

187 diameter of the specimen and the mean value of four lengths was calculated as the

188 length of the specimen. The average of diameters and lengths of three specimens was

189 taken as the representative diameter and length of each concrete, respectively. The 
190

corrosion depth for each concrete was calculated as follow:

$$
h_{i}=\left(d_{0}-d_{i}\right) / 2
$$

Where, $h_{i}$ is the corrosion depth at $i$ day $(\mathrm{mm}), d_{0}$ is the initial representative diameter before exposure to sulfuric acid $(\mathrm{mm}), d_{i}$ is the representative diameter after $i$ day exposure to sulfuric acid (mm).

\subsubsection{Mass loss}

Masses were measured with digital balance (0-30kg range and $1 \mathrm{~g}$ precision). The average of three specimens' masses was taken as the representative mass of each concrete.

\subsubsection{Impact resonance tests}

Most investigations have been used mass loss and corrosion depth as acceptable indicators for evaluating the resistance of concrete to sulfuric acid attack, but dynamic modulus of concrete after sulfuric acid corrosion was rarely studied. Dynamic elastic material constants of concrete may be used for quick assessment of material quality and uniformity [28-30]. Moreover, the dynamic test is a non-destructive testing (NDT) method, so the specimens used for this test can be used again for the following immersion test. In order to measure the dynamic modulus of elasticity, impact resonance test were performed according to ASTM C215-08[31], using the longitudinal mode. Fig. 2 shows a schematic of the impact resonance test used in this study. A miniature piezoelectric accelerometer that has a flat response from 1 to $12,000 \mathrm{~Hz}$ with a sensitivity of $10 \mathrm{mV} / \mathrm{g}$ at $160 \mathrm{~Hz}$ (LC0159 manufactured by lance) was mounted at the 
211 center of one end surface of the cylinder specimen. A steel ball with a diameter of 12

$212 \mathrm{~mm}$ was used as the impact source and applied at the center of the opposite end surface.

213 According to this setup, the data were recorded from the data acquisition system

214 and both the amplitude-time and amplitude-frequency graphs were obtained. From the

215 amplitude- frequency graph, the peak value which shows the resonant frequency value

216 of the concrete specimen was recorded in the computer. The average of three

217 specimens' fundamental longitudinal frequency was taken as the representative

218 fundamental longitudinal frequency of each concrete. The dynamic modulus of

219 elasticity was obtained from the following equations according to ASTM C215-08:

$$
E_{d}=5.093 M \times L \times d^{2} \times f^{2}
$$

221 Where $E_{d}$ is the dynamic modulus of elasticity. L, d, M, and $\mathrm{f}$ are the 222 representative value of the specimen's length, diameter, mass, and fundamental 223 longitudinal frequency, respectively.

\section{Results and discussion}

\section{$226 \quad 3.1$ Mechanism of concrete sulfuric acid corrosion}

Portland cement consists of pulverized cement clinker and gypsum. Cement

228 clinker consists of four major minerals: alite (mainly $3 \mathrm{CaO} \cdot \mathrm{SiO}_{2}$ ),

229 belite(mainly $2 \mathrm{CaO} \cdot \mathrm{SiO}_{2}$ ), aluminate phase (mainly $3 \mathrm{CaO} \cdot \mathrm{Al}_{2} \mathrm{O}_{3}$ ) and ferrite phase

230 (mainly $4 \mathrm{CaO} \cdot \mathrm{Al}_{2} \mathrm{O}_{3} \cdot \mathrm{Fe}_{2} \mathrm{O}_{3}$ ), as well as some impurities. Alite and belite, which are

231 calcium silicates, comprise around $85 \%$ of cement clinker[32]. At the early stage of 
232

concrete, $3 \mathrm{CaO} \cdot \mathrm{SiO}_{2}$ and $2 \mathrm{CaO} \cdot \mathrm{SiO}_{2}$ react with water to produce calcium silicate hydrate (abbreviated as C-S-H) and calcium hydroxide $\left(\mathrm{Ca}(\mathrm{OH})_{2}\right)[21]$. The $\mathrm{Ca} / \mathrm{Si}$ ratio of C-S-H in neat Portland cement pastes varies from 1.2 to 2.3 with a mean of 1.75 [33]. $3 \mathrm{CaO} \cdot 2 \mathrm{SiO}_{2} \cdot 3 \mathrm{H}_{2} \mathrm{O}$ and $2 \mathrm{CaO} \cdot \mathrm{SiO}_{2} \cdot 1.167 \mathrm{H}_{2} \mathrm{O}$ are suppose to be two representative constituents of C-S-H. So corrosion of concrete due to sulfuric acid can be characterized by the following reactions:

$$
\begin{gathered}
\mathrm{Ca}(\mathrm{OH})_{2}+\mathrm{H}_{2} \mathrm{SO}_{4} \rightarrow \mathrm{CaSO}_{4} \cdot 2 \mathrm{H}_{2} \mathrm{O} \\
\left(2 \mathrm{CaO} \cdot \mathrm{SiO}_{2}\right)+2 \mathrm{H}_{2} \mathrm{SO}_{4}+4 \mathrm{H}_{2} \mathrm{O} \rightarrow 2 \mathrm{CaSO}_{4} \cdot 2 \mathrm{H}_{2} \mathrm{O}+\mathrm{Si}(\mathrm{OH})_{4} \\
\left(3 \mathrm{CaO} \cdot \mathrm{SiO}_{2}\right)+3 \mathrm{H}_{2} \mathrm{SO}_{4}+5 \mathrm{H}_{2} \mathrm{O} \rightarrow 3 \mathrm{CaSO}_{4} \cdot 2 \mathrm{H}_{2} \mathrm{O}+\mathrm{Si}(\mathrm{OH})_{4} \\
3 \mathrm{CaO} \cdot 2 \mathrm{SiO}_{2} \cdot 3 \mathrm{H}_{2} \mathrm{O}+3 \mathrm{H}_{2} \mathrm{SO}_{4}+4 \mathrm{H}_{2} \mathrm{O} \rightarrow 3 \mathrm{CaSO} 4 \cdot 2 \mathrm{H}_{2} \mathrm{O}+2 \mathrm{Si}(\mathrm{OH})_{4} \\
2 \mathrm{CaO} \cdot \mathrm{SiO}_{2} \cdot 1.167 \mathrm{H}_{2} \mathrm{O}+2 \mathrm{H}_{2} \mathrm{SO}_{4}+2.833 \mathrm{H}_{2} \mathrm{O} \rightarrow 2 \mathrm{CaSO} 4 \cdot 2 \mathrm{H}_{2} \mathrm{O}+\mathrm{Si}(\mathrm{OH})_{4} \\
3 \mathrm{CaO} \cdot \mathrm{Al}_{2} \mathrm{O}_{3} \cdot 12 \mathrm{H}_{2} \mathrm{O}+3\left(\mathrm{CaSO} 4 \cdot 2 \mathrm{H}_{2} \mathrm{O}\right)+14 \mathrm{H}_{2} \mathrm{O} \rightarrow 3 \mathrm{CaO} \cdot \mathrm{Al}_{2} \mathrm{O}_{3} \cdot 3 \mathrm{CaSO} \cdot 32 \mathrm{H}_{2} \mathrm{O}
\end{gathered}
$$

It can be seen from the above chemical reaction equations, Sulfuric acid penetrates into concrete and reacts first with the calcium hydroxide $\left(\mathrm{Ca}(\mathrm{OH})_{2}\right)$, calcium silicates (not involved in hydration) and calcium silicate hydrate $(\mathrm{C}-\mathrm{S}-\mathrm{H})$ in the concrete to form gypsum ( $\mathrm{CaSO} 4 \cdot 2 \mathrm{H}_{2} \mathrm{O}$ ). This process could decrease the performance of concrete since gypsum has barely no strength. Then the gypsum would react with calcium aluminate hydrate to form ettringite $\left(\mathrm{CaO} \cdot \mathrm{Al}_{2} \mathrm{O}_{3} \cdot 3 \mathrm{CaSO}_{4} \cdot 32 \mathrm{H}_{2} \mathrm{O}\right)$. As the $\mathrm{pH}$ value decreases, calcium hydroxide (12.6), ettringite(10.7), C-S-H( $\approx 10.5)$ and finally calcium aluminate and ferrite hydrates decompose successively until a silica gel residue is obtained at $\mathrm{pH}$ values below roughly 2 (the value in parentheses referring to $\mathrm{pH}$ 
253 stability) [15]. So, ettringite is unstable in the sulfuric acid environment. After sulfuric

254 acid corrosion, a soft and pulpy layer with an increased porosity is formed on the

255 concrete eroded surface, which may dominantly compose of gypsum and silica gel

256 residue.

\subsection{Visual inspection}

Photographs were taken of cylinder specimens after immersion in the sulfuric acid

259 over regular time periods to record changes in surface appearance. Typical surface

260 appearances of four types of concrete cylinders after 164 days immersion in sulfuric

261 acid solution with a pH around 0.95 are shown in Fig.3. It is clearly shown in Fig.3 that

262 cylinders of concrete C1F1, containing gravel and river sand has suffered the most

263 severe damage with exposure of coarse aggregates and significant loss of cement

264 mortar. The specimens' surface of concrete C1F1 and C2F1 became significantly

265 rougher than $\mathrm{C} 1 \mathrm{~F} 2$ and $\mathrm{C} 2 \mathrm{~F} 2$ after immersion in sulfuric acid, which appeared to

266 indicate that those concretes containing river sand as fine aggregate were more

267 vulnerable to acid attack. Surface appearances of cylinders of concrete C1F1 during the

268 period of 194 days immersion in $\mathrm{pH} \approx 0.95$ sulfuric acid are shown in Fig.4. The

269 corrosion process is clearly shown in the photograph: the uncorroded surface was flat

270 and smooth casted by steel mold. At the initial stage of corrosion (0 37 days), the

271 corroded surface became soft and white because of the formation of corrosion products

272 (speculated to be mainly gypsum $[11,15,25,34]$ ) deposit on the cylindrical surface.

273 When the corrosion continued, the corroded concrete lost its fine aggregates (37 108 
274 days) and coarse aggregates (108 194 days).

275

276
<Fig. 3>

<Fig. 4>

\subsection{Corrosion depth and mass loss and dynamic modulus of elasticity loss}

The corrosion depth of each concrete can be calculated by Eq. (1) as previously mentioned. The other indicators for evaluating the resistance of concrete to sulfuric acid attack, including mass loss and dynamic modulus of elasticity loss were calculated by the following Eq.(9) and Eq.(10), respectively.

$$
\begin{gathered}
K_{m}=\left(m_{i}-m_{0}\right) / m_{0} \times 100 \% \\
K_{E d}=\left(E_{d i}-E_{d 0}\right) / E_{d 0} \times 100 \%
\end{gathered}
$$

Where, $K_{m}$ and $K_{E d}$ represent mass loss and dynamic modulus of elasticity loss, respectively. $m_{0}$ and $E_{d 0}$ represent mass and dynamic modulus of elasticity before exposure to sulfuric acid, respectively. $m_{i}$ and $E_{d i}$ represent mass and dynamic modulus of elasticity after exposure to sulfuric acid $i$ days.

It can be observed in Fig. 5 that the trend of concrete specimens' corrosion depths versus corrosion time was similar. The corrosion depths of all the cylinders were negative values at the initial stage of corrosion ( $0 \sim 37$ days), and then became positive values as the corrosion continues. A negative value represents an expansion of the cylinders compared to the initial dimensions, while a positive value means that due to loss of material, the radius of the cylinder decreased compares to the initial size. This could be attributed to the formation of gypsum, which was difficult to brush from the 
295 surfaces at the initial corrosion stage. As the corrosion continued, corrosion depths

296 became deeper because of the detachment of corrosion products, fine and coarse

297 aggregates from the specimens. The corrosion depths for C1F1, C1F2, C2F1, and

298 C2F2 concrete specimens after 194 days of immersion in sulfuric acid were $6.04 \mathrm{~mm}$,

$2992.64 \mathrm{~mm}, 3.34 \mathrm{~mm}$, and $2.25 \mathrm{~mm}$, respectively.

301 The cylinders' mass changes of each concrete with the immersion time in the 302 sulfuric acid solution is plotted in Fig.6. As shown in this figure, all the cylinders had 303 mass gain over the first 21 days immersion in the acid solution. And then cylinders of 304 concrete C1F1 started to lose mass with immersion time. The others began to lose 305 mass after 52 days immersion. The mass gain during the early immersion period 306 could be attributed to a number of factors, which include continued hydration of 307 cement and formation of gypsum. Since locations of fine and coarse aggregates lost 308 due to deep degradation in the cement paste of the specimen, the mass loss decreased.

309 The mass loss for $\mathrm{C} 1 \mathrm{~F} 1, \mathrm{C} 1 \mathrm{~F} 2, \mathrm{C} 2 \mathrm{~F} 1$, and $\mathrm{C} 2 \mathrm{~F} 2$ concrete specimens after 194 days 310 of immersion in sulfuric acid were $26.5 \%, 13.95 \%, 18.75 \%, 11.56 \%$, respectively. The similar tendency of concrete specimens' changes in dynamic modulus of

313 elasticity loss versus corrosion time under sulfuric acid actions was shown in Fig.7. At 314 the initial stage, the dynamic modulus of elasticity of deteriorated specimens increased 315 slightly, and then decreased gradually. The increase of dynamic modulus of elasticity 
316 could be attributed to the formation of gypsum, which deposited within the pore of

317 concrete so as to increase the compactness at the initial stage. And then, the volume

318 expansion caused by gypsum will increase in internal pressure and subsequently cause

319 internal cracking and pitting. These damages could lead to the reduction in dynamic

320 modulus of elasticity in the following corrosion process. The dynamic modulus of

321 elasticity loss for C1F1, C1F2, C2F1, and C2F2 concrete specimens after 194 days of

322 immersion in sulfuric acid were $11.44 \%, 3.2 \%, 13.77 \%, 5.31 \%$, respectively.

324 As shown in Fig.5, Fig.6 and Fig.7, aggregates type had a pronounced effect on

325 corrosion depth, mass loss and dynamic modulus of elasticity loss. These could

326 attribute the reasons as follow. In concrete containing siliceous aggregates, only cement

327 hydration products react with acid and the effect of neutralization during acid attack

328 would be very limited. However, marble aggregates are composed mainly of calcium

329 carbonate, which will react with acid and the concrete would then have much greater

330 capacity to neutralize acid. The neutralization effect of sacrificial marble aggregates

331 could significantly reduce the local acid concentration and the rate of acid attack on

332 concrete $[12,19]$. The chemical equation of calcium carbonate and sulfuric acid [35] is

333 given as Eq. (11).

$$
\mathrm{CaCO}_{3}+\mathrm{H}_{2} \mathrm{SO}_{4}+\mathrm{H}_{2} \mathrm{O} \rightarrow \mathrm{CaSO}_{4} \cdot 2 \mathrm{H}_{2} \mathrm{O}+\mathrm{CO}_{2}
$$

335 Advantageous effect of marble aggregate containing mainly of calcium carbonate in 336 sulfuric acid resistance could also been found in the aspect of thermodynamics. The 
337 Gibbs free energy is defined in terms of thermodynamic properties that are state

338 functions. The Gibbs energy change $\Delta_{r} G_{m}^{\ominus}$ is a useful tool to describe in what

339 manner the reaction is conducted. If $\Delta_{r} G_{m}^{\ominus}<0$, the reaction is spontaneous in the

340 forward direction, which means the reaction could proceed in the forward direction on

341 its own without any outside assistance. Superscript " $\ominus$ " means standard state (298

342 Kelvin and 1atm pressure), subscript "m" means 1 molar, subscript " $r$ " means reaction.

343 The change in Gibbs free energy under standard-state is a function of the change in two

344 terms: enthalpy and entropy, as expressed by the Gibbs-Helmholtz

345 equation: $\Delta_{r} G_{m}^{\ominus}=\Delta_{r} H_{m}^{\ominus}-T \Delta_{r} S_{m}^{\ominus}$. For a chemical reaction $a A+b B \rightarrow d D+e E$ (the

346 reactants $\mathrm{A}$ and $\mathrm{B}$ combine to form products $\mathrm{D}$ and $\mathrm{E}$, and $\mathrm{a}, \mathrm{b}, \mathrm{d}$, e are the

347 stoichiometric coefficients for corresponding species), the enthalpy change $\Delta_{r} H_{m}^{\ominus}$

348 and the entropy change $\Delta_{r} S_{m}^{\ominus}$ for the reaction under standard-state can be expressed

349 as:

$350 \Delta_{r} H_{m}^{\ominus}=\sum \Delta_{r} H_{m}^{\ominus}($ products $)-\sum \Delta_{r} H_{m}^{\ominus}($ reactants $)=\left[d \Delta_{f} H_{m}^{\ominus}(D)+e \Delta_{f} H_{m}^{\ominus}(E)\right]-\left[a \Delta_{f} H_{m}^{\ominus}(A)+b \Delta_{f} H_{m}^{\ominus}(B)\right]$

$351 \Delta_{r} S_{m}^{\ominus}=\sum \Delta_{r} S_{m}^{\ominus}$ (products) $-\sum \Delta_{r} S_{m}^{\ominus}($ reactants $)=\left[d \Delta_{f} S_{m}^{\ominus}(D)+e \Delta_{f} S_{m}^{\ominus}(E)\right]-\left[a \Delta_{f} S_{m}^{\ominus}(A)+b \Delta_{f} S_{m}^{\ominus}(B)\right]$

352 where $\Delta_{f} H_{m}^{\ominus}$ and $\Delta_{f} S_{m}^{\ominus}$ (subscript "f" means formation) denote the molar enthalpy

353 and entropy of formation of a compound from its constituent elements at standard state

354 respectively. $\Delta_{f} H_{m}^{\ominus}$ and $\Delta_{f} S_{m}^{\ominus}$ values can be found in the handbook of minerals and

355 the related compounds thermodynamic data[36], or be queried through HSC

356 Chemistry® v. 5.0[37]. The standard molar enthalpies $\Delta_{f} H_{m}^{\ominus}$ and entropies $\Delta_{f} S_{m}^{\ominus}$

357 of formation of compounds needed to compute $\Delta_{r} H_{m}^{\ominus}$ and $\Delta_{r} S_{m}^{\ominus}$ (subscript "r" 
358 negative, and the logarithm of the equilibrium constants $\left(\log \left(K^{\ominus}\right)\right)$ are greater than 5. It 378 indicates that all the reaction can go to completion. It can be seen from Eq. (3) (7) in

\section{$<$ Table 5>}

The equilibrium constant $K^{\ominus}$ is related to the standard Gibbs free energy change $\Delta_{r} G_{m}^{\ominus}$ by the following equation: $\Delta_{r} G_{m}^{\ominus}=-R T \ln K^{\ominus}=-2.303 R T \log K^{\ominus}$, where $\mathrm{T}$ is the absolute temperature in Kelvin, and $\mathrm{R}$ is the gas constant with a value of $8.314 \mathrm{~J} \cdot(\mathrm{mol} \cdot \mathrm{K})^{-1}$. This equation allows us to calculate the equilibrium constant for any reaction from the standard-state Gibbs free energy change of reaction. The larger the equilibrium constant $K^{\ominus}$, the farther the reaction has to go to reach equilibrium. Usually, if the logarithm of the equilibrium constant $(\log (\mathrm{K}))$ is greater than 5 , the reaction can go to completion. Results of thermodynamic calculation for Eq. (3) (7) \& (11) are given in Table 6. In order to be better understood the thermodynamic calculation results in Table 5, taking chemical reaction Eq. (6) as example, thermodynamic calculations are provided as follows:

$\Delta_{r} H_{m}^{\ominus}=[-3 \times 2022.629-2 \times 1456.961]-[-4782.312-3 \times 813.989-4 \times 285.930]=-613.808 \mathrm{~kJ} \cdot \mathrm{mol}^{-1}$ $\Delta_{r} S_{m}^{\ominus}=[3 \times 194.1-2 \times 500.503]-[312.126+3 \times 156.904+4 \times 69.95]=-1481.344 \mathrm{~J} \cdot \mathrm{mol}^{-1} \cdot \mathrm{K}^{-1}$ $\Delta_{r} G_{m}^{\ominus}=\Delta_{r} H_{m}^{\ominus}-T \Delta_{r} S_{m}^{\ominus}=-613.808-298 \times\left(-1481.344 \div 10^{3}\right)=-172.367 \mathrm{~kJ} \cdot \mathrm{mol}^{-1}$ $\log K^{\ominus}=-\Delta_{r} G_{m}^{\ominus} /(2.303 R T)=172.367 \times 10^{3} /(2.303 \times 8.314 \times 298)=30.21$

\section{$<$ Table 6>}

As shown in Table 6, Gibbs free energy changes $\left(\Delta_{r} G_{m}^{\ominus}\right)$ of the six reactions are 
Table 6, calcium silicates $\left(3 \mathrm{CaO} \cdot \mathrm{SiO}_{2}, 2 \mathrm{CaO} \cdot \mathrm{SiO}_{2}\right)$, calcium hydroxide $\left(\mathrm{Ca}(\mathrm{OH})_{2}\right)$ and

calcium silicate hydrates $\left(3 \mathrm{CaO} \cdot 2 \mathrm{SiO}_{2} \cdot 3 \mathrm{H}_{2} \mathrm{O}\right.$ and $\left.2 \mathrm{CaO} \cdot \mathrm{SiO}_{2} \cdot 1.167 \mathrm{H}_{2} \mathrm{O}\right)$ are

381 vulnerable to sulfuric acid attack. It can explain why concrete cannot be immune from

382 acid attack. Results of thermodynamic calculation for Eq. (11) indicate calcium carbonate

383 which is the main component of marble aggregates, will react with sulfuric acid

384 spontaneous. So the concrete containing marble aggregates would then have much

385 greater capacity to sulfuric neutralize acid.

\section{Corrosion regression model}

Correctly calculation and prediction of corrosion depth is necessary to accurately

estimate the minimum thickness of the concrete cover in reinforced concrete structures

or to adequately design for sacrificial layers in concrete structures exposed to sulfuric

390 acid solutions[38].Many researchers developed models to predict the corrosion depth of

391 the concrete in acid environment. It is generally believed that the degradation depth of

392 concrete due to acid attack including sulfuric acid attack is proportional to the square

393 root of the exposure time as follows[39]:

$$
h=b \sqrt{t}
$$

Where, $\mathrm{h}$ is the degradation depth, $\mathrm{t}$ is the exposure time in acid solution and $\mathrm{b}$ is

396 constant. According to this equation, the rate of degradation is dominated by the

397 diffusion rate of acid under the assumption that corrosion products remain on surface

$398[40,41]$. But in actual structures, concrete is often exposed to flowing water that

399 contains sulfuric acid such as sewage[42]. Because of almost no strength damaged zone, 
400 the corrosion products would be removed by the shearing force of flowing solution. In

401 these instances, it was predicted that concrete deterioration caused by sulfuric acid

402 attack would proceed at a greater rate than that predicted from the square root

403 relationship. Kawai et al.[42] found that the depth of erosion of concrete was nearly

404 proportional to the exposure time when concrete was exposed to flowing acid solution.

405 Pavlik [39] and Grube [43] also found when the corroded layer is stable due to the

406 absence of any external mechanical, corrosion depth or mass loss with time would

407 follow a parabolic function [44]. But a disturbance of the protective layer by external

408 mechanical effects, even if it occurs at relatively long intervals, the parabolic function

409 would turn to a linear one. In this experiment, in order to reduce differential

410 concentrations of the acid within the solution vessel after adding $98 \%$ sulfuric acid, the

411 solution was stirred once a day. Since stirring action generates the flow of solutions and

412 the shearing force of the flow is applied to the surfaces of the specimens. Moreover, the

413 protective layer was also largely interrupted when the specimens were periodically

414 removed from the acid solution. So the protective layer formed around concrete

415 specimens was largely interrupted in this study. So indicators (corrosion depth or mass

416 loss et al.) with time would follow a linear relationship. In addition, Daczko[45] found

417 that the mass of all the concrete specimens increased initially and after 50 days, the

418 mass of all the specimens decreased when exposed to $\mathrm{pH}=1$ sulfuric acid solution.

419 Chang[19] found that all the concrete cylinders had mass gain over the first 21 days

420 immersion in the acid solution and then started losing mass with immersion time when 
exposed to $1 \%$ sulfuric acid solution ( $\mathrm{pH}$ was kept in the range of 1.27 to 1.35 ). The cylinder specimens' crushing loads in his research were also recorded an increase before 56 days and then a decrease. It seems that hyperbolic function may be suitable for the relationship between indicators (corrosion depth or mass loss et al.) and time. In order to make a reasonable choice of corrosion depth regression models, take concrete $\mathrm{C} 2 \mathrm{~F} 1$ as an example. 12 experimental corrosion depths of concrete $\mathrm{C} 2 \mathrm{~F} 1$ obtained during 194 days were divided into two parts. 10 depths obtained from 0 136 days were used to fit the empirical model, and the remaining 2 depths obtained from 136 194 days were used to verify the fitted model. Fig.8 shows two fitting curves

430 including linear regression model recommended by previous studies[42, 43] and

431 hyperbolic regression model proposed in this paper when protective layer are 432 interrupted. Obviously the hyperbolic regression model is closer to the experimental 433 data than linear regression model. So a hyperbolic regression model could provide 434 better prediction to corrosion depths than linear relationship in this paper. The equation 435 of the hyperbolic regression model is given as follow:

$$
h=1 /\left(A \times t^{B}+C\right)+D \times t+E
$$

$438 \mathrm{D}$, and $\mathrm{E}$ are coefficients from regression. The curve fitting coefficients are listed in 439 Table 7 for corrosion depth. Fig. 9 shows the result of Eq. (13) and experimental data 440 of concrete corrosion depths. 

respectively.

451 Generally, the first derivative of the corrosion depth with respect to time represents the rate of the corrosion. When the corrosion time tends to infinity, the rate of deterioration tends to D (shown as Eq. (14)), which means that the coefficient D represents the ultimate rate of the concrete sulfuric acid.

$$
\lim _{t \rightarrow \infty} \frac{d h}{d t}=\lim _{t \rightarrow \infty}\left(\frac{-A \times B t^{B-1}}{A \times t^{B}+C}+D\right)=D
$$

456 After comparing parameter D in Table 7, the corrosion rate in the terms of corrosion 457 depth and mass loss was sorted in the following sequence: C1F1 (gravel and river sand) $>\mathrm{C} 2 \mathrm{~F} 1$ (marble stone and river sand) $>\mathrm{C} 1 \mathrm{~F} 2$ ( gravel and marble sand) $>\mathrm{C} 2 \mathrm{~F} 2$ (marble stone and marble sand). The corrosion rate in the aspect of dynamic modulus of elasticity loss was sorted in the following sequence: $\mathrm{C} 1 \mathrm{~F} 1>\mathrm{C} 2 \mathrm{~F} 1>\mathrm{C} 2 \mathrm{~F} 2>\mathrm{C} 1 \mathrm{~F} 2$. The

461 cylinders of concrete $\mathrm{C} 2 \mathrm{~F} 2$, containing marble stone and sand had the best performance 462 in the terms of corrosion depth and mass loss. This could attribute to the marble 
463

464

465

466

467

468

469

472

473

474

475

aggregates, which locally creating a buffering environment and protecting the cement paste, showed a smaller degradation depth and mass loss than the concrete with inert aggregates. However, the cylinders of concrete C1F2, containing gravel and marble sand had the best performance in the terms of dynamic modulus of elasticity. It is speculated that the dynamic modulus of elasticity of the gravel exposed on cylindrical surface would be less damaged than the marble stone, which could react with the sulfuric acid.

The orthogonal design is a mathematical method used for planning multifactor tests. Because there were two factors at two different levels in this test as previous mentioned, the orthogonal table $\mathrm{L}_{4}(2)^{3}$ was used to arrange the tests. In this case, two factors were coarse aggregate and fine aggregate. Two levels were gravel (C1) and marble stone (C2) for coarse aggregate, and river sand (F1) and marble sand (F2) for fine aggregate. The range analysis was adopted to clarify the significance of coarse and fine aggregate on the concrete sulfuric acid corrosion rate, which could be represented as regression coefficient $\mathrm{D}$. The results of range analysis are given in Table 8 . The $\mathrm{K}$ value represents the average of the two values of each level for each factor. $\mathrm{R}$ is the absolute value of the difference between $\mathrm{K} 1$ and $\mathrm{K} 2$. A large $\mathrm{R}$ value indicates the significant effect of the influencing factor[46]. According to the results of range analysis showed in Table 8, Effect of fine aggregate on concrete sulfuric acid corrosion rate is more significant than coarse aggregate in the terms of corrosion depth, mass loss, and dynamic modulus of elasticity loss. The reason could be attributed to the large 
484 surface to volume ratios of the fine aggregate. Take a sphere with the radius of " $r$ " for 485 example, surface area equals to " $4 \pi r^{2}$ " and volume equals to " $4 \pi r^{3} / 3$ ". 486 Surface-area-to-volume ratio of the sphere equals to $3 / a$, which means the greater the 487 radius of a sphere, the lower the surface area to volume ratio. As shown in Table 2 and 488 Table 3, coarse aggregate is predominantly greater than $9.5 \mathrm{~mm}$, while fine aggregate 489 is predominantly less than $1.18 \mathrm{~mm}$. So the surface-area-to-volume ratio of the fine 490 aggregates is bigger than that of coarse aggregates. In chemical reactions involving a 491 solid material, the surface area to volume ratio is an important factor for the reactivity.

492 Materials with high surface area to volume ratio react at much faster rates than 493 monolithic materials, because larger surface is available to react for a unit volume. So 494 the marble sand will react with sulfuric acid more complete and will neutralize more 495 sulfuric acid than marble stone. $<$ Table 8>

\section{Conclusion}

498 1) The dynamic modulus of elasticity loss can be regard as an acceptable indicator for 499 evaluating concrete sulfuric acid resistance as well as corrosion depth and mass loss.

500 2) A hyperbolic regression model was proposed in this paper, which could provide

501 better prediction to indicators than linear relationship when concrete sulfuric acid

502 corrosion layer interrupted. The model parameter D in the model has easily understood 503 physical meanings, which represents the ultimate rate of the concrete sulfuric acid.

504 3) The corrosion rate in the terms of corrosion depth and mass loss was sorted in the 
511 fine aggregate on concrete sulfuric acid corrosion rate is more significant than coarse aggregate in the terms of corrosion depth, mass loss, and dynamic modulus of elasticity

513 loss.

\section{Acknowledgments}

515 The authors would like to acknowledge the financial supports by the National science foundation

516 (51208373) and the Shanghai Pujiang Program (12PJ1409000).Special thanks are extended to

517 Associate prof. Hesheng Tang at Tongji University, China.

\section{References :}

519 [1] Chandra AP, Gerson AR. The mechanisms of pyrite oxidation and leaching: A fundamental 520 perspective. Surface Science Reports. 2010;65(9):293-315.

521 [2] Fan Y, Hu Z, Zhang Y, Liu J. Deterioration of compressive property of concrete under simulated 522 acid rain environment. Construction and Building Materials. 2010;24(10):1975-83.

523 [3] Araghi HJ, Nikbin IM, Reskati SR, Rahmani E, Allahyari H. An experimental investigation on 524 the erosion resistance of concrete containing various PET particles percentages against sulfuric acid 525 attack. Construction and Building Materials. 2015;77:461-71.

526 [4] Vincke E, Verstichel S, Monteny J, Verstraete W. A new test procedure for biogenic sulfuric acid 527 corrosion of concrete. Biodegradation. 1999;10(6):421-8.

528 [5] O'Connell M, McNally C, Richardson MG. Performance of concrete incorporating GGBS in 529 aggressive wastewater environments. Construction and Building Materials. 2012;27(1):368-74.

530 [6] Hewayde E, Nehdi ML, Allouche E, Nakhla G. Using concrete admixtures for sulphuric acid 531 resistance. Proceedings of the ICE-Construction Materials. 2007;160(1):25-35.

532 [7] Ehrich S, Helard L, Letourneux R, Willocq J, Bock E. Biogenic and chemical sulfuric acid 
533 corrosion of mortars. Journal of Materials in Civil Engineering. 1999;11(4):340-4.

534 [8] Hughes BP, Fattuhi NI. SRPC and modified concretes subjected to severe sulphuric acid attack.

535 Magazine of Concrete Research. 1988;40:159-66.

536 [9] Zivica V, Bajza A. Acidic attack of cement based materials - a review Part 2. Factors of rate of 537 acidic attack and protective measures. Construction and Building Materials. 2002;16(4):215-22.

538 [10] Roy DM, Arjunan P, Silsbee MR. Effect of silica fume, metakaolin, and low-calcium fly ash on 539 chemical resistance of concrete. Cement and Concrete Research. 2001;31(12):1809-13.

540 [11] Torii K, Kawamura M. Effects of fly ash and silica fume on the resistance of mortar to sulfuric 541 acid and sulfate attack. Cement and Concrete Research. 1994;24(94):361-70.

542 [12] Makhloufi Z, Kadri EH, Bouhicha M, Benaissa A. Resistance of limestone mortars with 543 quaternary binders to sulfuric acid solution. Construction and Building Materials. 544 2012;26(1):497-504.

545 [13] Xiong G, Chen X, Li G, Chen L. Sulphuric acid resistance of soluble soda glass-polyvinyl 546 acetate latex-modified cement mortar. Cement and concrete research. 2001;31(1):83-6.

547 [14] Araghi HJ, Nikbin IM, Reskati SR, Rahmani E, Allahyari H. An experimental investigation on 548 the erosion resistance of concrete containing various PET particles percentages against sulfuric acid 549 attack. Construction and Building Materials. 2015;77:461-71.

550 [15] Beddoe RE, Dorner HW. Modelling acid attack on concrete: Part I. The essential mechanisms. 551 Cement and Concrete Research. 2005;35(12):2333-9.

552 [16] MA Dz. Aggregate selection for concrete in acid environment. Industrial Construction. 553 1989;12:39-41.

554 [17] Hughes BP, Guest JE. Limestone and siliceous aggregate concretes subjected to sulphuric acid 555 attack. Magazine of Concrete Research. 1978;30(102):11-8.

556 [18] De Belie N, Monteny J, Beeldens A, Vincke E, Van Gemert D, Verstraete W. Experimental 557 research and prediction of the effect of chemical and biogenic sulfuric acid on different types of 558 commercially produced concrete sewer pipes. Cement and Concrete Research. 559 2004;34(12):2223-36.

560 [19] Chang ZT, Song XJ, Munn R, Marosszeky M. Using limestone aggregates and different 561 cements for enhancing resistance of concrete to sulphuric acid attack. Cement and Concrete 562 Research. 2005;35(8):1486-94.

563 [20] Bederina M, Makhloufi Z, Bounoua A, Bouziani T, Quéneudec M. Effect of partial and total 564 replacement of siliceous river sand with limestone crushed sand on the durability of mortars 565 exposed to chemical solutions. Construction and Building Materials. 2013;47(5):146-58.

566 [21] Yang L, Zhang Y, Liu Z, Zhao P, Liu C. In-situ tracking of water transport in cement paste using 567 X-ray computed tomography combined with CsCl enhancing. Materials Letters. 2015;160:381-3.

568 [22] Ning Y. Research on application of diabase-fine-sand concrete in expressway engineering. 569 Wuhan: Wuhan University of Technology; 2003.

570 [23] Limbachiya M, Marrocchino E, Koulouris A. Chemical-mineralogical characterisation of 571 coarse recycled concrete aggregate. Waste Management. 2007;27(2):201-8.

572 [24] Hewlett P. Lea's chemistry of cement and concrete: Butterworth-Heinemann; 2003.

573 [25] Bassuoni MT, Nehdi ML. Resistance of self-consolidating concrete to sulfuric acid attack with 574 consecutive pH reduction. Cement and Concrete Research. 2007;37(7):1070-84. 
[26] Girardi F, Maggio RD. Resistance of concrete mixtures to cyclic sulfuric acid exposure and mixed sulfates: Effect of the type of aggregate. Cement and Concrete Composites. 2011;33(2):276-85.

[27] Živica Vr. Acidic attack of cement based materials-a review Part 3: research and test methods. Construction and Building Materials. 2004;18(9):683-8.

[28] Zhou Y, Gao J, Sun Z, Qu W. A fundamental study on compressive strength, static and dynamic elastic moduli of young concrete. Construction and Building Materials. 2015;98:137-45.

[29] Trtnik G, Kavčič F, Turk G. Prediction of concrete strength using ultrasonic pulse velocity and artificial neural networks. Ultrasonics. 2009;49(1):53-60.

[30] Kolluru S, Popovics J, Shah S. Determining Elastic Properties of Concrete Using Vibrational Resonance Frequencies of Standard Test Cylinders. Cement, Concrete and aggregates. 2000;22(2):81-9.

[31] American Society for Testing Material. ASTM C215-08 Standard Test Method for Fundamental Transverse, Longitudinal, and Torsional Resonant Frequencies of Concrete Specimens. West Conshohocken, Pennsylvania,USA,2008.

[32] Xu S. The static Mechanical properties and anti-penetration characteristics of Ultra-high performace cementitious composites. Nanjing: Nanjing University of Science and Technology; 2012.

[33] Zhang Y, Sun W, Liu S. Study on the hydration heat of binder paste in high-performance concrete. Cement and Concrete Research. 2002;32(9):1483-8.

[34] Zhou Q, Hill J, Byars EA, Cripps JC, Lynsdale CJ, Sharp JH. The role of pH in thaumasite sulfate attack. Cement and Concrete Research. 2006;36(1):160-70.

[35] Girardi F, Di Maggio R. Resistance of concrete mixtures to cyclic sulfuric acid exposure and mixed sulfates: Effect of the type of aggregate. Cement \& Concrete Composites. 2011;33(2):276-85.

[36] LIN C. The handbook of minerals and the related compounds thermodynamic data. Beijing: Science Press; 1985.

[37] Roine A. HSC Chemistry® v. 5.0. Chemical Reaction and Equilibrium Software with Extensive Thermochemical Database Product Instruction Manual. 2002.

[38] Attogbe EK, RizkallaI SH. Response of concrete to sulfuric acid attack. ACI Materials Journal. 1988;85(6):481-8.

[39] Pavlik V. Corrosion of hardened cement paste by acetic and nitric acids part I : Calculation of corrosion depth. Cement and concrete research. 1994;24(3):551-62.

[40] Yuan HF, Dangla P, Chatellier P, Chaussadent T. Degradation modelling of concrete submitted to sulfuric acid attack. Cement and Concrete Research. 2013;53:267-77.

[41] Rendell F, Jauberthie R. The deterioration of mortar in sulphate environments. Construction and Building Materials. 1999;13(99):321-7.

[42] Kawai K, Yamaji S, Shinmi T. Concrete deterioration caused by sulfuric acid attack. 10 th DBMC International Conference On Durability of Building Materials and Component2005.

[43] Grube H, Rechenberg W. Durability of concrete structures in acidic water. Cement and Concrete Research. 1989;19(2):783-92.

[44] ALLAHVERDI A, ŠKVÁRA F. Acidic corrosion of hydrated cement based materials.Part 2 - 
617 kinetics of the phenomenon and mathematical models. Ceramics- Silikáty. 2000;44(4):152-60.

618 [45] Daczko JA, Johnson DA, Amey SL. Decreasing concrete sewer pipe degradation using 619 admixtures. Materials Performance. 1997;36(1):51-6.

620 [46] Zhu G, Ju H. Determination of naproxen with solid substrate room temperature phosphorimetry 621 based on an orthogonal array design. Analytica chimica acta. 2004;506(2):177-81.

622 


\section{Tables}

624

625

626

627

628

629

Table 1 Chemical composition of two types of aggregates (\% by mass)

\begin{tabular}{cccccccccc}
\hline Constituent & $\mathrm{SiO}_{2}$ & $\mathrm{Al}_{2} \mathrm{O}_{3}$ & $\mathrm{Fe}_{2} \mathrm{O}_{3}$ & $\mathrm{MgO}$ & $\mathrm{CaO}$ & $\mathrm{Na}_{2} \mathrm{O}$ & $\mathrm{K}_{2} \mathrm{O}$ & $\mathrm{P}_{2} \mathrm{O}_{5}$ & $\mathrm{CO}_{3}$ \\
\hline Gravel & 59.323 & 14.923 & 4.089 & 1.134 & 3.487 & 4.449 & 3.914 & nd & 7.831 \\
Marble & nd & nd & 0.028 & nd & 56.636 & 0.002 & 0.008 & 0.034 & 44.134 \\
Sand[22] & 78.56 & 7.02 & 2.58 & 0.78 & 3.66 & 1.51 & 1.39 & nd & nd \\
\hline
\end{tabular}

630

*Note : nd means content is lower than the limit of detection.

631

632

633

634

635

636

637

638

639 
640

641

642

643

644

645

646

647

648

Table 2 Results of sieving test for gravel

\begin{tabular}{ccccccc}
\hline Sieve size $(\mathrm{mm})$ & 26.5 & 19 & 16 & 9.5 & 4.75 & 2.36 \\
\hline Grader retained (\%) & 0 & 25 & 22 & 30 & 19 & 4 \\
Accumulated retained (\%) & 0 & 25 & 47 & 77 & 96 & 100 \\
\hline
\end{tabular}

649

650

651

652

653

654

655

656

657 
658

659

660

661

662

663

664

665

666

Table 3 Results of sieving test of river sand

\begin{tabular}{ccccccccc}
\hline Sieve size (mm) & 9.5 & 4.75 & 2.36 & 1.18 & 0.6 & 0.3 & 0.15 & Bottom \\
\hline Grader retained (\%) & 0 & 5.6 & 10.8 & 10.2 & 17.8 & 44.4 & 9.2 & 2 \\
Accumulated retained (\%) & 0 & 5.6 & 16.4 & 26.6 & 44.4 & 88.8 & 98 & 100 \\
\hline
\end{tabular}

667

668

669

670

671

672

673

674

675 
676

677

678

679

680

681

682

683

Table 4 Mix proportions for concrete specimens $\left(\mathrm{kg} / \mathrm{m}^{3}\right)$

\begin{tabular}{ccccc}
\hline Specimens & Water & Cement & Fine & Coarse \\
& & & aggregate & aggregate \\
\hline $\mathrm{C} 1 \mathrm{~F} 1$ & 205 & 456 & 516 & 1149 \\
$\mathrm{C} 1 \mathrm{~F} 2$ & 205 & 456 & 522 & 1162 \\
$\mathrm{C} 2 \mathrm{~F} 1$ & 205 & 456 & 507 & 1129 \\
$\mathrm{C} 2 \mathrm{~F} 2$ & 205 & 456 & 513 & 1141 \\
\hline
\end{tabular}

684

685

686

687

688

689

690 
691

692

693

694

695

696 Table 5 Compounds standard molar enthalpies and entropies of formation in Eq. (3) (7) \& (11)

\begin{tabular}{ccc|ccc}
\hline Compound & $\begin{array}{c}\Delta_{f} \mathrm{H}_{m}^{\ominus} \\
/ \mathrm{kJ} \cdot \mathrm{mol}^{-1}\end{array}$ & $\begin{array}{c}\Delta_{f} \mathrm{~S}_{m}^{\ominus} \\
/ \mathrm{J} \cdot \mathrm{mol}^{-1} \cdot \mathrm{K}^{-1}\end{array}$ & Compound & $\begin{array}{c}\Delta_{f} \mathrm{H}_{m}^{\ominus} \\
/ \mathrm{kJ} \cdot \mathrm{mol}^{-1}\end{array}$ & $\begin{array}{c}\Delta_{f} \mathrm{~S}_{m}^{\ominus} \\
/ \mathrm{J} \cdot \mathrm{mol}^{-1} \cdot \mathrm{K}^{-1}\end{array}$ \\
\hline $\mathrm{Ca}(\mathrm{OH})_{2}$ & -985.9 & 83.4 & $\mathrm{Si}(\mathrm{OH})_{4}$ & -1456.961 & -500.503 \\
$\mathrm{CaSO}_{4} \cdot 2 \mathrm{H}_{2} \mathrm{O}$ & -2022.629 & 194.1 & $3 \mathrm{CaO} \cdot \mathrm{SiO}_{2}$ & -2929.202 & 168.598 \\
$\mathrm{H}_{2} \mathrm{SO}_{4}$ & -813.989 & 156.904 & $\mathrm{H}_{2} \mathrm{O}$ & -285.93 & 69.950 \\
$2 \mathrm{CaO} \cdot \mathrm{SiO}_{2}$ & -2315.216 & 120.792 & $\mathrm{CaCO}_{3}$ & -1206.6 & 91.710 \\
$2 \mathrm{CaO} \cdot \mathrm{SiO}_{2}$ & -2665.208 & 160.666 & $3 \mathrm{CaO} \cdot 2 \mathrm{SiO}_{2}$ & -4782.312 & 312.126 \\
$\cdot 1.167 \mathrm{H}_{2} \mathrm{O}$ & $-39 \mathrm{H}_{2} \mathrm{O}$ & & \\
$\mathrm{CO}_{2}$ & -39.505 & 213.769 & & & \\
\hline
\end{tabular}

697

698

699

700

701

702

703

704

705 
706

707

708

709

710

711

712

713 Table 6 Results of thermodynamic calculation for Eq. (3) (7) \& (11)

\begin{tabular}{cccc} 
Chemical equation & Eq. & $\begin{array}{c}\Delta_{r} \mathrm{G}_{m}^{\ominus} \\
l k J \cdot \mathrm{mol}^{-1}\end{array}$ & $\mathrm{log} \mathrm{K}^{\ominus}$ \\
\hline $\mathrm{Ca}(\mathrm{OH})_{2}+\mathrm{H}_{2} \mathrm{SO}_{4} \rightarrow \mathrm{CaSO}_{4} \cdot 2 \mathrm{H}_{2} \mathrm{O}$ & $(3)$ & -208.97 & 36.62 \\
& & & \\
$\left(2 \mathrm{CaO} \cdot \mathrm{SiO}_{2}\right)+2 \mathrm{H}_{2} \mathrm{SO}_{4}+4 \mathrm{H}_{2} \mathrm{O} \rightarrow 2 \mathrm{CaSO}_{4} \cdot 2 \mathrm{H}_{2} \mathrm{O}+\mathrm{Si}(\mathrm{OH})_{4}$ & $(4)$ & -168.95 & 29.61 \\
& & & \\
$\left(3 \mathrm{CaO} \cdot \mathrm{SiO}_{2}\right)+3 \mathrm{H}_{2} \mathrm{SO}_{4}+5 \mathrm{H}_{2} \mathrm{O} \rightarrow 3 \mathrm{CaSO}_{4} \cdot 2 \mathrm{H}_{2} \mathrm{O}+\mathrm{Si}(\mathrm{OH})_{4}$ & $(5)$ & -453.66 & 79.51 \\
$\left(3 \mathrm{CaO} \cdot 2 \mathrm{SiO}_{2} \cdot 3 \mathrm{H}_{2} \mathrm{O}\right)+3 \mathrm{H}_{2} \mathrm{SO}_{4}+4 \mathrm{H}_{2} \mathrm{O} \rightarrow$ & & & \\
$3\left(\mathrm{CaSO} 4 \cdot 2 \mathrm{H}_{2} \mathrm{O}\right)+2 \mathrm{Si}\left(\mathrm{OH}_{4}\right.$ & $(6)$ & -172.367 & 30.21 \\
$\left(2 \mathrm{CaO} \cdot \mathrm{SiO}_{2} \cdot 1.167 \mathrm{H}_{2} \mathrm{O}\right)+2 \mathrm{H}_{2} \mathrm{SO}_{4}+2.833 \mathrm{H}_{2} \mathrm{O} \rightarrow$ & & & \\
$2\left(\mathrm{CaSO} 4 \cdot 2 \mathrm{H}_{2} \mathrm{O}\right)+\mathrm{Si}_{(\mathrm{OH})_{4}}$ & $(7)$ & -165.079 & 28.93 \\
$\mathrm{CaCO} \mathrm{O}_{3}+\mathrm{H}_{2} \mathrm{SO}_{4}+\mathrm{H}_{2} \mathrm{O} \rightarrow \mathrm{CaSO}_{4} \cdot 2 \mathrm{H}_{2} \mathrm{O}+\mathrm{CO}_{2}$ & $(11)$ & -136.23 & 23.88 \\
\hline
\end{tabular}

714

715

716

717

718

719 
720

721

722

723

724

725

726

727

728

729

730

731

732

733

734

735

736

737

738

739

740 
Table 7 Regression coefficients of Eq. (13)

\begin{tabular}{|c|c|c|c|c|c|c|c|}
\hline Indicators & Specimens & A & B & $\mathrm{C}$ & D & $\mathrm{E}$ & Adj. $R^{2}$ \\
\hline \multirow{4}{*}{$\begin{array}{c}\text { Corrosion } \\
\text { depth }\end{array}$} & $\mathrm{C} 1 \mathrm{~F} 1$ & 0.0075 & 1.3634 & 0.6480 & 0.0390 & -1.5415 & 0.997 \\
\hline & $\mathrm{C} 1 \mathrm{~F} 2$ & 0.0311 & 1.6136 & 1.3580 & 0.0177 & -0.7404 & 0.998 \\
\hline & $\mathrm{C} 2 \mathrm{~F} 1$ & 0.0076 & 3.1670 & 1.4812 & 0.0215 & -0.6755 & 0.993 \\
\hline & $\mathrm{C} 2 \mathrm{~F} 2$ & 0.0215 & 2.3422 & 2.9692 & 0.0142 & -0.3384 & 0.984 \\
\hline \multirow{4}{*}{ Mass loss } & $\mathrm{C} 1 \mathrm{~F} 1$ & -0.0029 & 1.7437 & -0.1991 & -0.1657 & 5.0827 & 0.998 \\
\hline & $\mathrm{C} 1 \mathrm{~F} 2$ & -0.0082 & 1.5722 & -0.2258 & -0.0973 & 4.4581 & 0.992 \\
\hline & $\mathrm{C} 2 \mathrm{~F} 1$ & -0.0069 & 2.5943 & -0.2470 & -0.1227 & 4.0510 & 0.992 \\
\hline & $\mathrm{C} 2 \mathrm{~F} 2$ & -0.0625 & 1.2695 & -0.2922 & -0.0815 & 3.4263 & 0.985 \\
\hline \multirow{4}{*}{$\begin{array}{c}\text { Dynamic } \\
\text { modulus } \\
\text { of } \\
\text { elasticity } \\
\text { loss }\end{array}$} & $\mathrm{C} 1 \mathrm{~F} 1$ & 12.0395 & -1.9100 & 0.1530 & -0.0700 & -4.7536 & 0.969 \\
\hline & $\mathrm{C} 1 \mathrm{~F} 2$ & 16.9162 & -2.1097 & 0.13692 & -0.0245 & -5.4834 & 0.596 \\
\hline & $\mathrm{C} 2 \mathrm{~F} 1$ & 8.2627 & -1.3283 & 0.1909 & -0.0696 & -5.3059 & 0.895 \\
\hline & $\mathrm{C} 2 \mathrm{~F} 2$ & 7.3259 & -1.1099 & 0.1570 & -0.0379 & -3.3778 & 0.674 \\
\hline
\end{tabular}

746

747

748

749

750 
Table 8 Range analysis for coefficient D

\begin{tabular}{|c|c|c|c|c|}
\hline Indicators & Specimens & $\begin{array}{c}\text { Coarse } \\
\text { aggregate }\end{array}$ & $\begin{array}{c}\text { Fine } \\
\text { aggregate }\end{array}$ & $\begin{array}{l}\text { Coefficient D in } \\
\text { Eq.(10) }\end{array}$ \\
\hline \multirow{7}{*}{$\begin{array}{l}\text { Corrosion } \\
\text { depth }\end{array}$} & $\mathrm{C} 1 \mathrm{~F} 1$ & 1 & 1 & 0.0390 \\
\hline & $\mathrm{C} 1 \mathrm{~F} 2$ & 1 & 2 & 0.0177 \\
\hline & $\mathrm{C} 2 \mathrm{~F} 1$ & 2 & 1 & 0.0215 \\
\hline & $\mathrm{C} 2 \mathrm{~F} 2$ & 2 & 2 & 0.0142 \\
\hline & $K 1$ & 0.028 & 0.030 & \\
\hline & $K 2$ & 0.018 & 0.016 & \\
\hline & $R$ & 0.010 & 0.014 & \\
\hline \multirow{7}{*}{ Mass loss } & C1F1 & 1 & 1 & -0.1657 \\
\hline & $\mathrm{C} 1 \mathrm{~F} 2$ & 1 & 2 & -0.0973 \\
\hline & $\mathrm{C} 2 \mathrm{~F} 1$ & 2 & 1 & -0.1227 \\
\hline & $\mathrm{C} 2 \mathrm{~F} 2$ & 2 & 2 & -0.0815 \\
\hline & $K 1$ & -0.132 & -0.144 & \\
\hline & $K 2$ & -0.102 & -0.089 & \\
\hline & $R$ & 0.030 & 0.055 & \\
\hline \multirow{7}{*}{$\begin{array}{c}\text { Dynamic } \\
\text { modulus of } \\
\text { elasticity loss }\end{array}$} & C1F1 & 1 & 1 & -0.0700 \\
\hline & $\mathrm{C} 1 \mathrm{~F} 2$ & 1 & 2 & -0.0245 \\
\hline & $\mathrm{C} 2 \mathrm{~F} 1$ & 2 & 1 & -0.0696 \\
\hline & $\mathrm{C} 2 \mathrm{~F} 2$ & 2 & 2 & -0.0379 \\
\hline & $K 1$ & -0.047 & -0.070 & \\
\hline & $K 2$ & -0.054 & -0.031 & \\
\hline & $R$ & 0.007 & 0.039 & \\
\hline
\end{tabular}


755

Figures

756

757

758

759

760
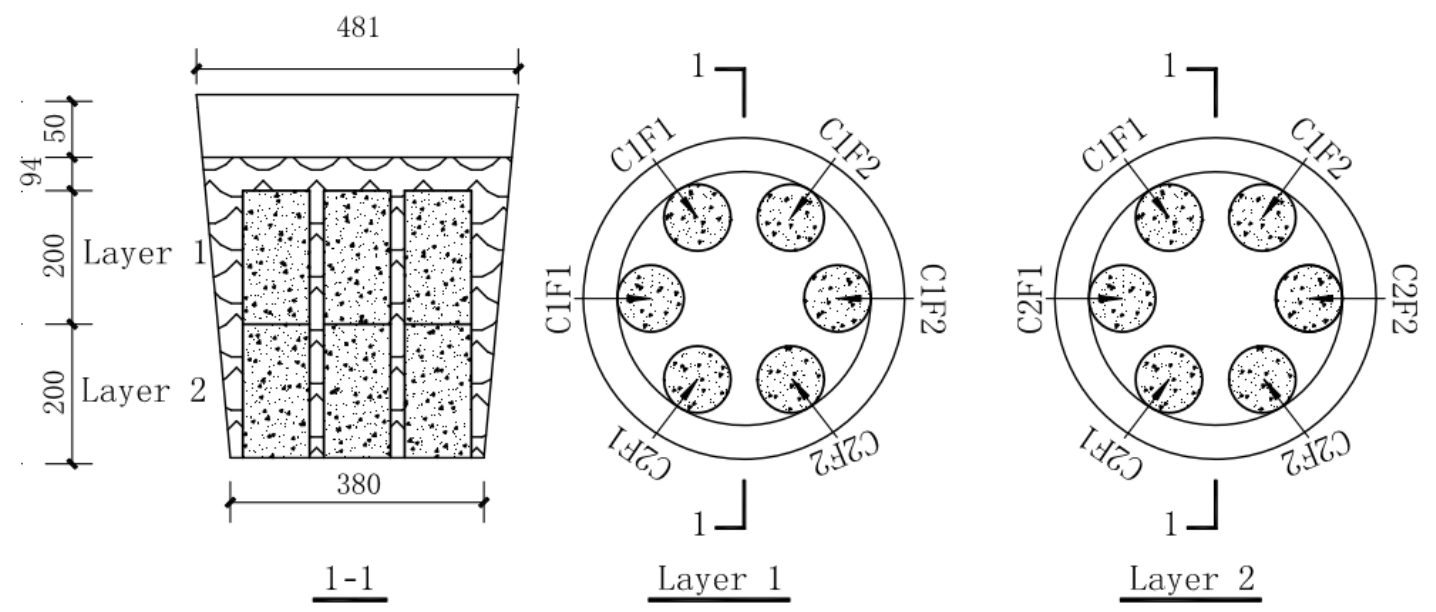

761

762

Fig.1 Specimens immersion arrangement

763

764

765

766

767

768

769

770 


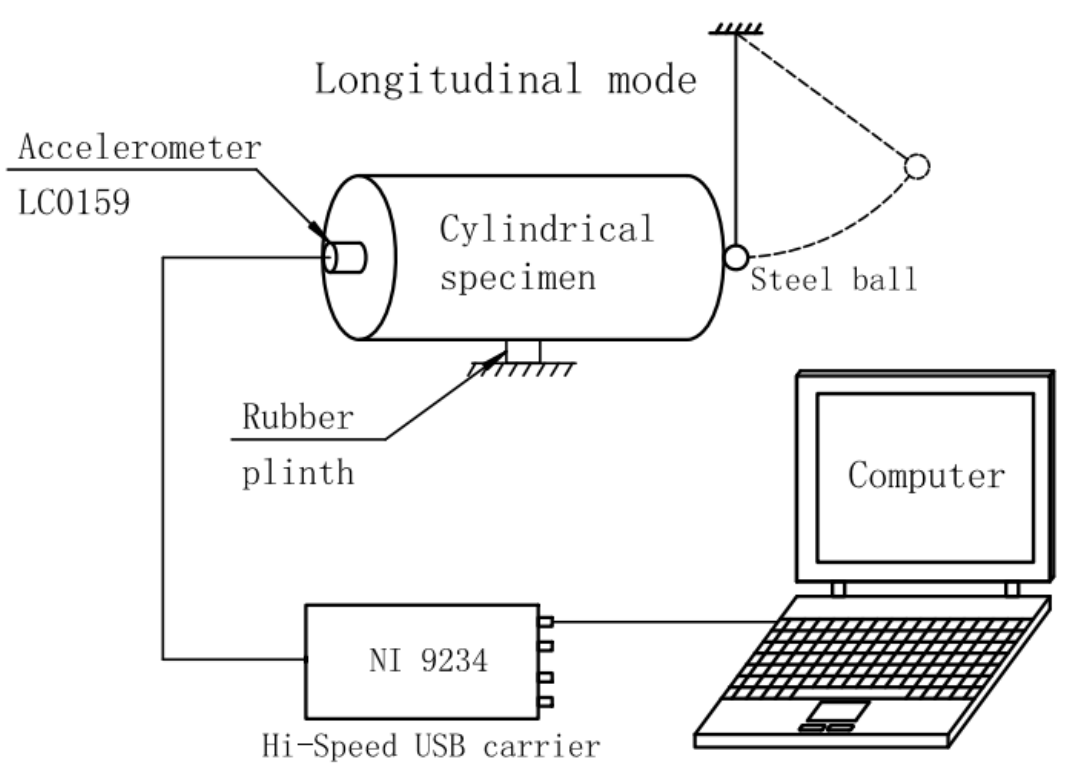


786

787

788

789

790

791

792

793

794

795

796

797

798

799

800

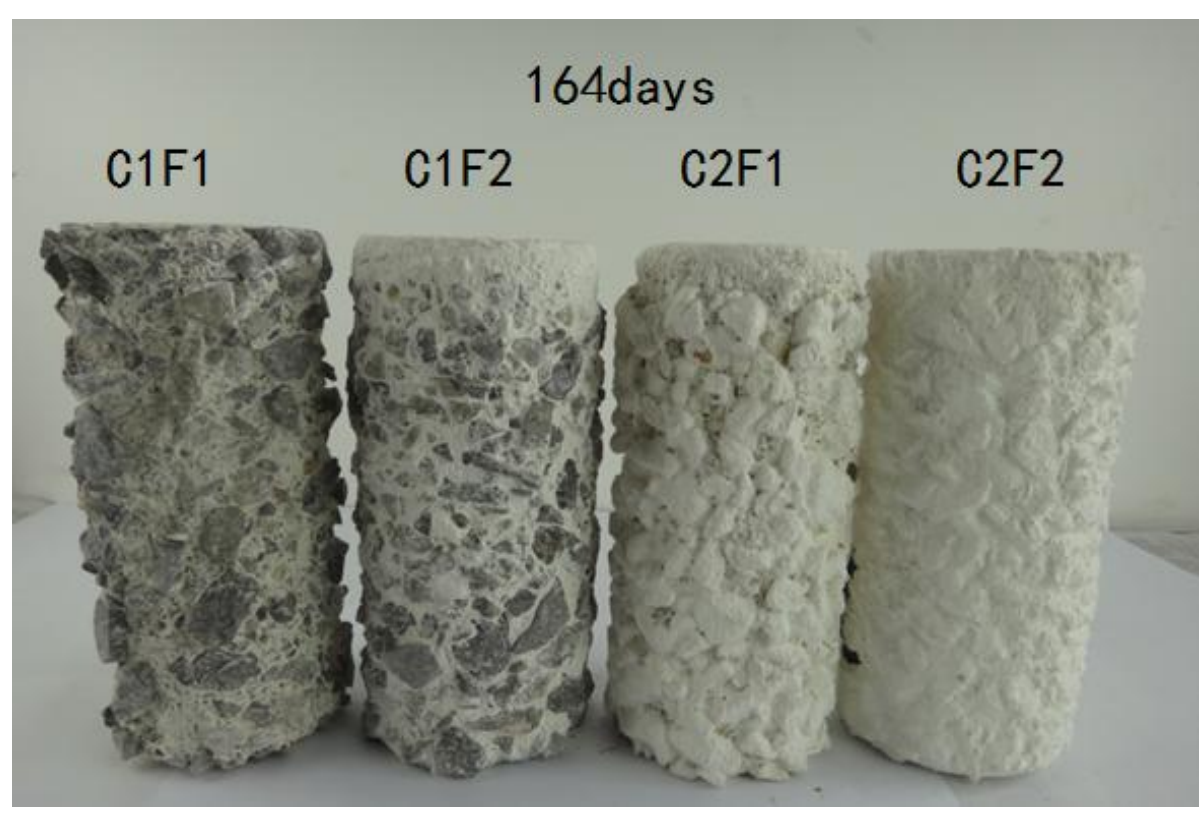

Fig.3 Appearance of concrete cylinders after 164 days corrosion 
801

802

803

804

805

806
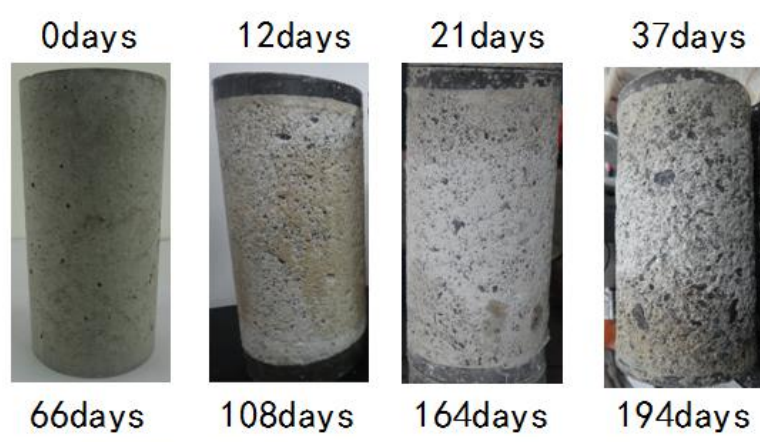

807
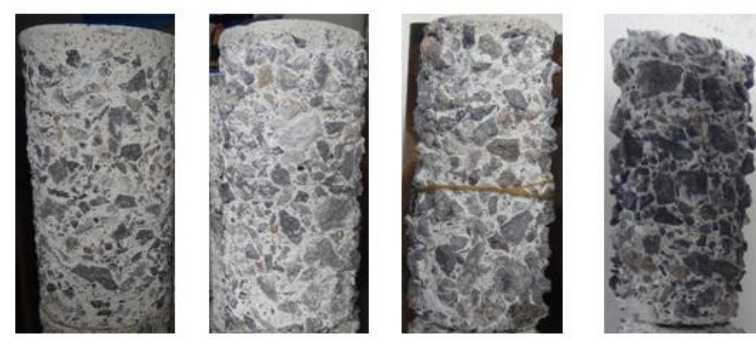

Fig.4 Appearances of concrete cylinders (C1F1) during 194 days corrosion

808

809

810

811

812

813

814

815 
816

817

818

819

820

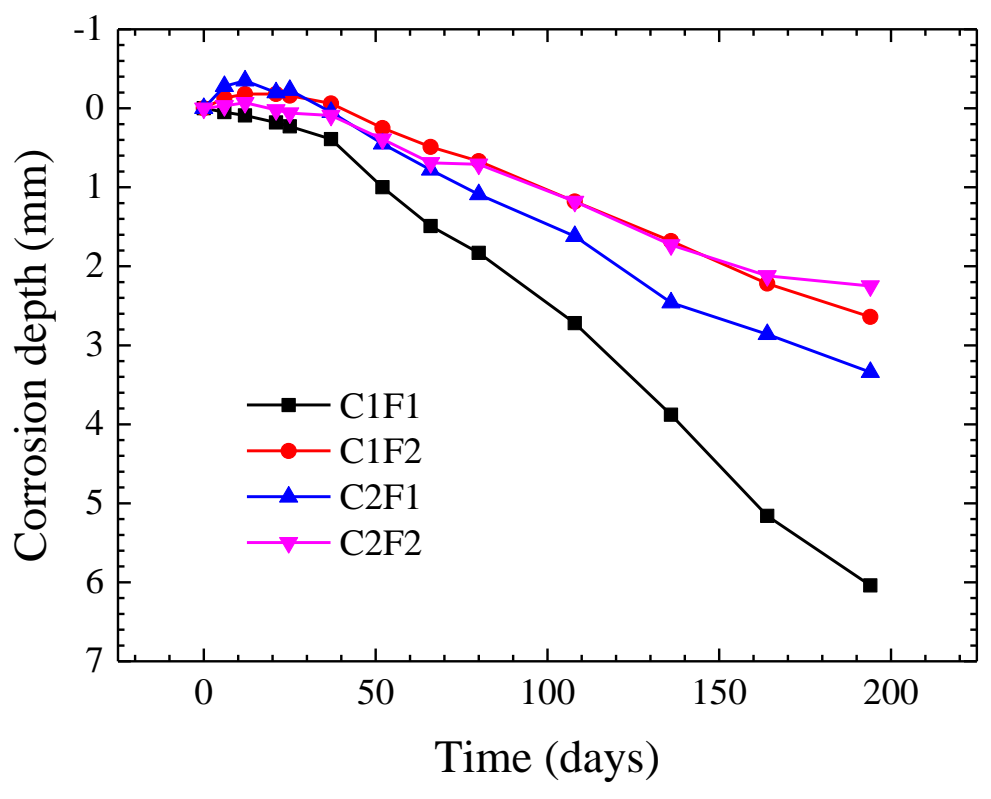

821

Fig.5 Relationship between corrosion depth and time 


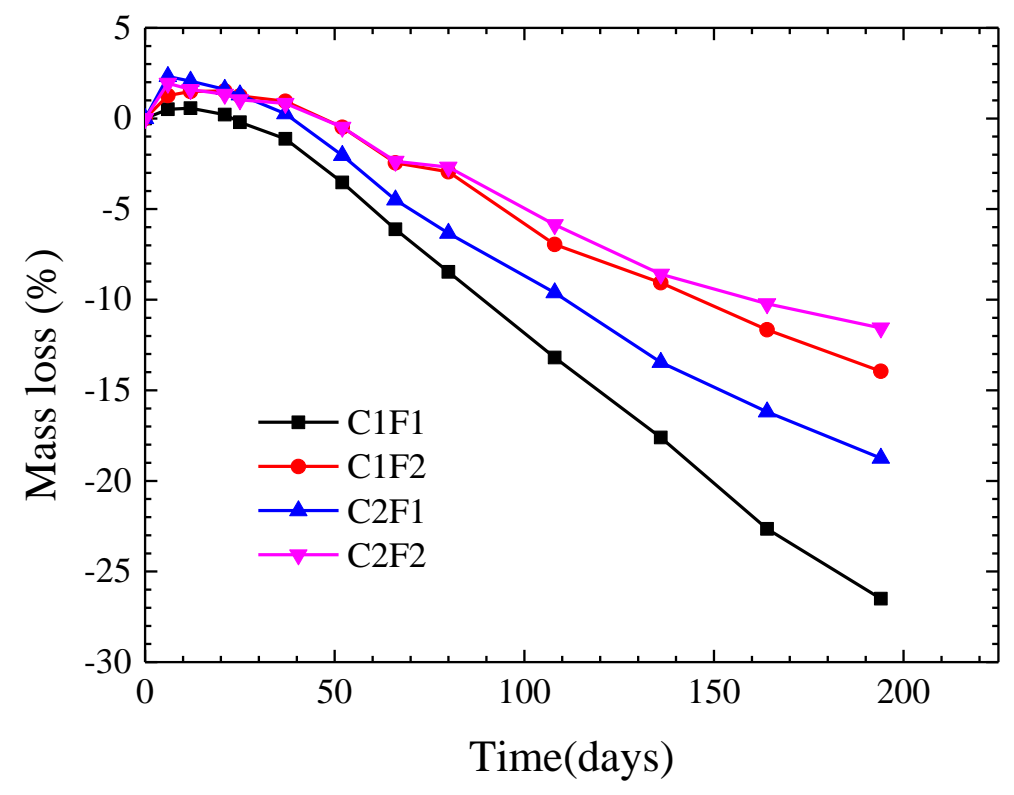


846

847

848

849

850

851

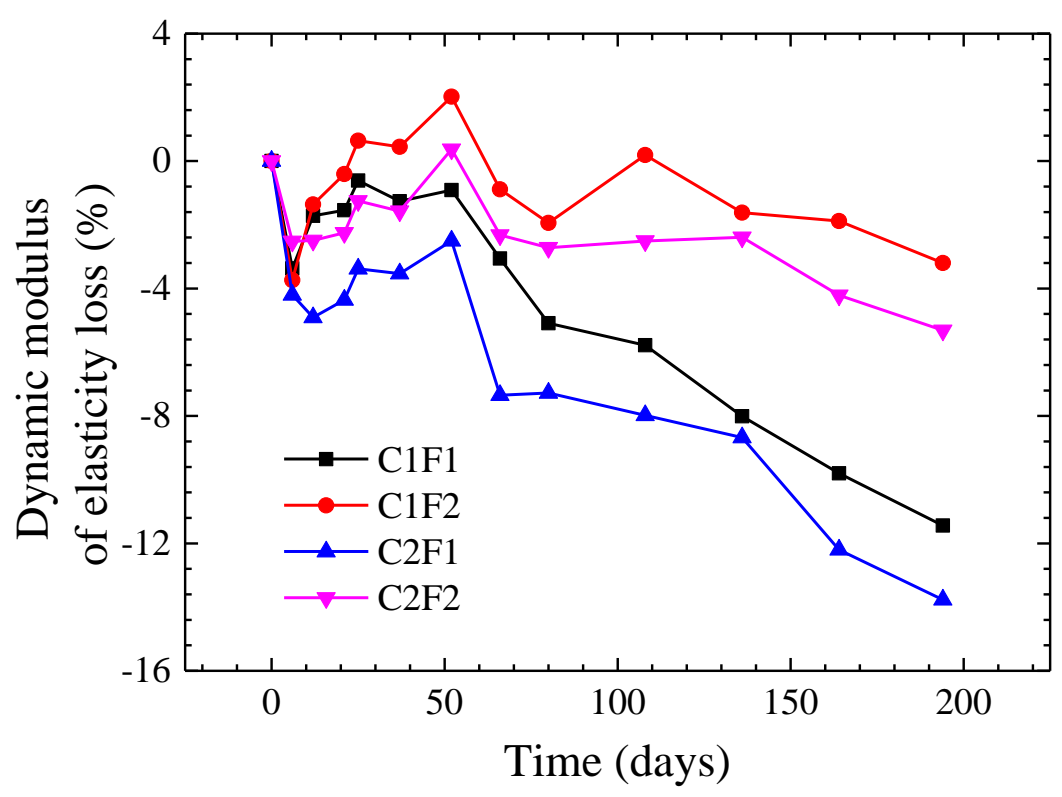

852

Fig.7 Relationship between dynamic modulus of elasticity loss and time

853

854

855

856

857

858

859

860 


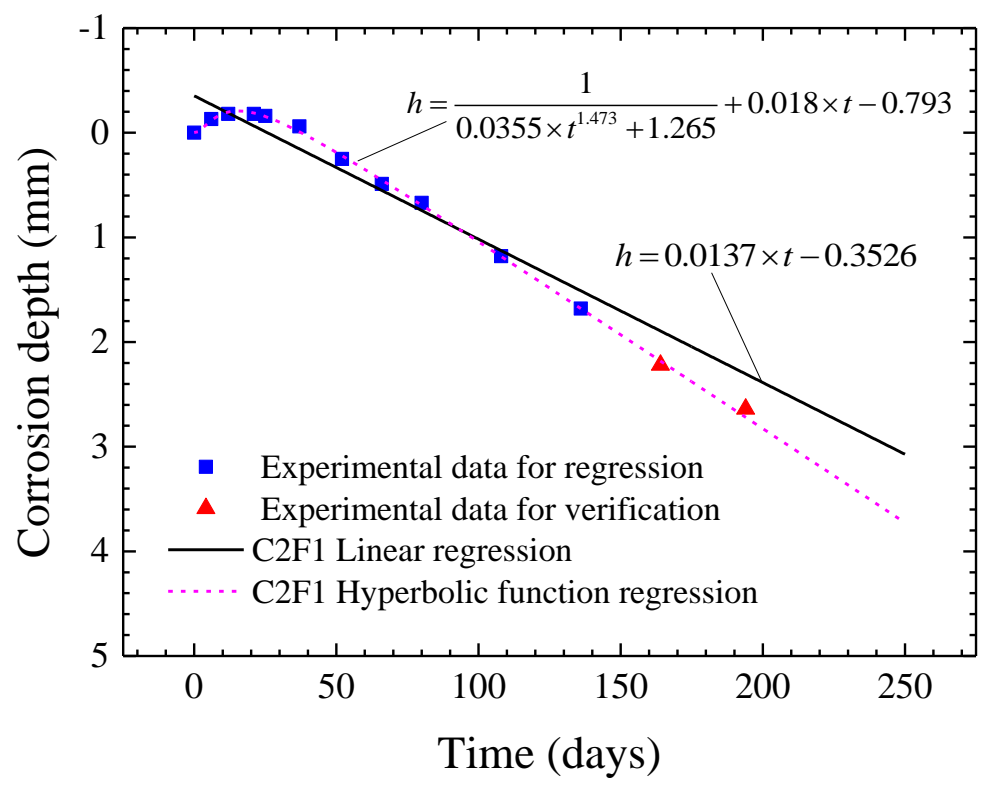

867 Fig.8 Comparison of hyperbolic and linear models with test results of $\mathrm{C} 2 \mathrm{~F} 1$ corrosion depth

868

869

870

871

872

873

874

875 


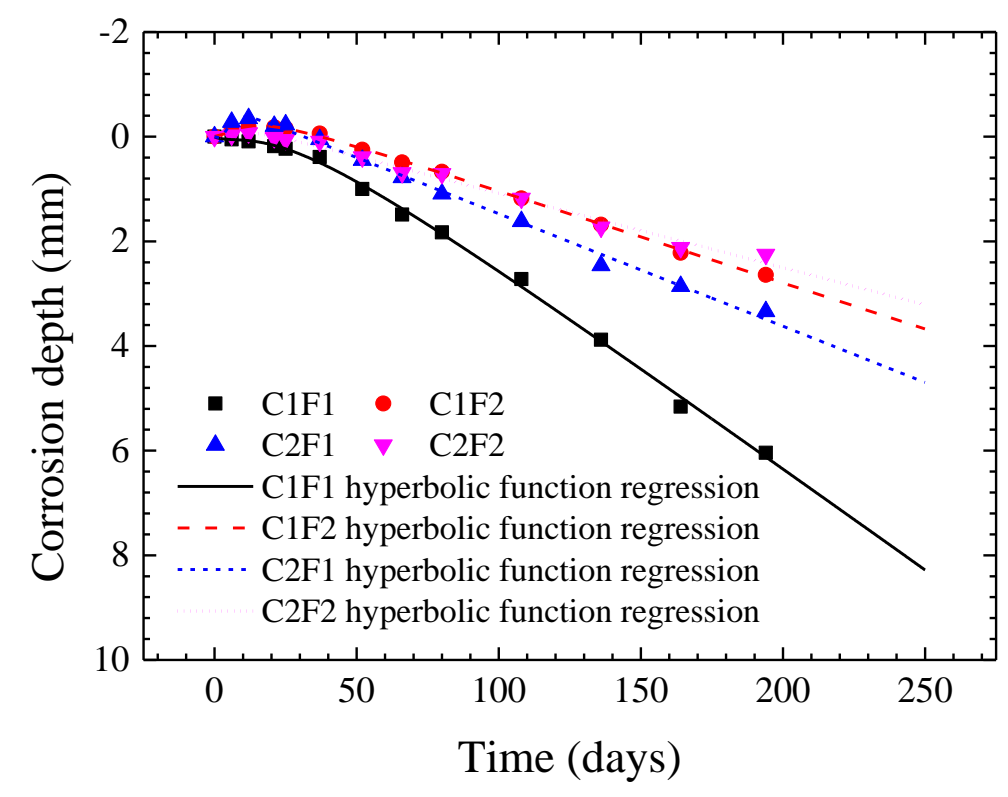




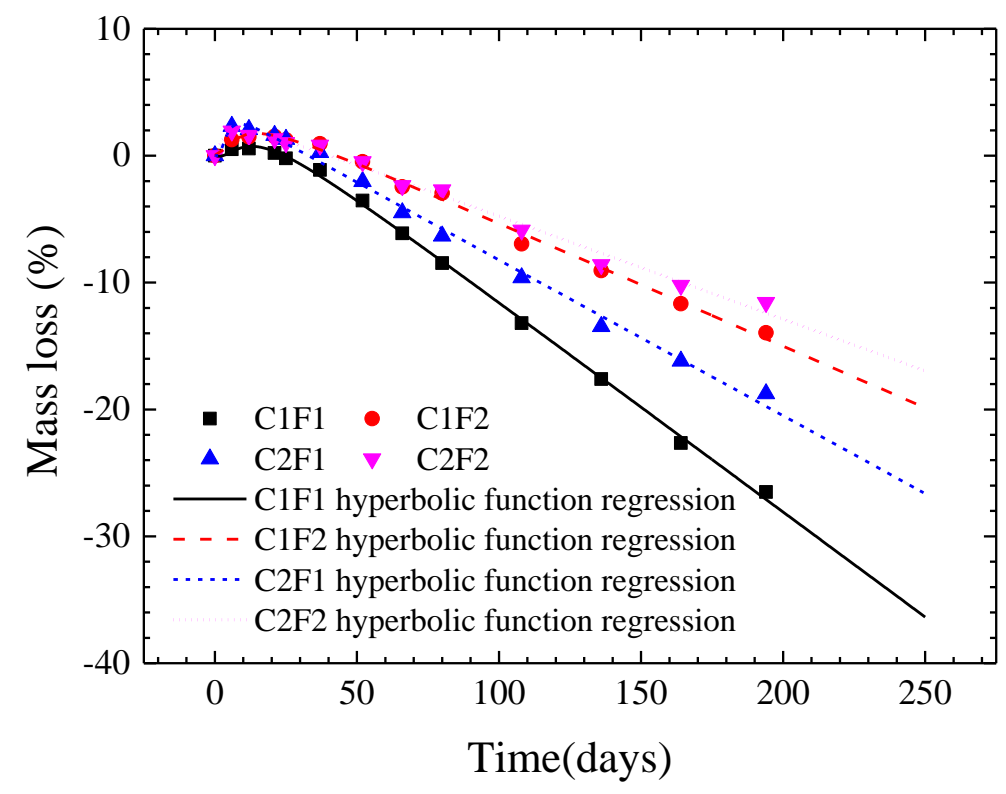




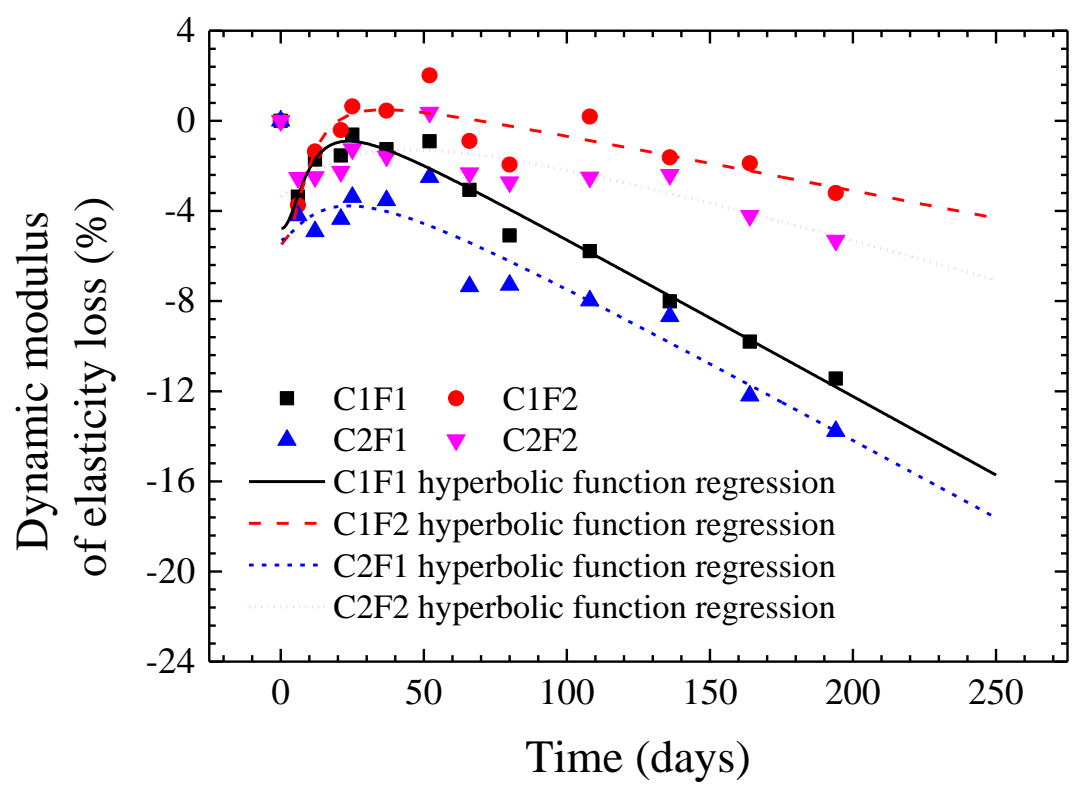

911 Fig.11 Comparison of hyperbolic model with test results of dynamic modulus of elasticity loss

912

913

914

915

916

917

918 